\title{
Analisis Kadar Formalin Pada Tahu Yang Beredar Di Pasar Kecamatan Ujung Bulu Kabupaten Bulukumba
}

\author{
${ }^{1}$ Arfiani Nur \\ ${ }^{2}$ Rahmatia Sam \\ 3Asdinar \\ ${ }^{4}$ Aisyah \\ ${ }^{5}$ Rahmiani Gani \\ ${ }^{6}$ Syarifah Rabiatul Adawiah \\ ${ }^{7}$ Titik Andriani
}

\footnotetext{
1,4,5,6,7 Jurusan Kimia,Fakultas Sains dan Teknologi,UIN Alauddin Makassar,Indonesia

${ }^{2,3}$ Prodi DIII Analis Kesehatan,STIKES Panrita Husada Bulukumba,Indonesia
}

\author{
Alamat Korespondensi: \\ Arfiani Nur \\ Kimia \\ UIN Alauddin Makassar \\ 085230970706 \\ arfianinur@gmail.com
}




\begin{abstract}
ABSTRAK
Food and Agriculture Organization (FAO) dan World Health Organization (WHO) menyatakan bahwa bahan tambahan makanan adalah bahan-bahan yang ditambahkan dengan sengaja ke dalam makanan dalam jumlah sidikit untuk memperbaiki warna, bentuk, citarasa, tekstur, atau sebagai pengawet. Menurut PerKBPOM No. 2 tahun 3013 tentang Bahan Berbahaya yang disalahgunakan dalam pangan salah satunya adalah formalin.Penelitian ini bertujuan untuk menganalisis kandungan formalin dalam tahu yang kemungkinan beredar di pasar tradisional kabupaten Bulukumba. Teknik sampling yang digunakan adalah Total Sampling. Metode analisis kualitatif formalin dilakukan dengan metode fenilhidrazin dan analisis kuantitatifnya dengan metode spektrofotometri. Sampel tahu diambil di Pasar Kecematan Ujung Bulu Kabupaten Bulukumba. Hasil penelitian menunjukkan dari 10 sampel tahu yang dibeli dari 10 penjual terdapat 3 sampel tahu yang mengandung formalin (30\%). Kadar formalin dalam sampel tahu pada ketiga penjual tersebut adalah $10 \mathrm{ppm}, 9,8 \mathrm{ppm}, 9,5 \mathrm{ppm}$. Disarankan kepada pedagang agar tidak menggunakan formalin sebagai bahan tambahan pangan dan masyarakat agar berhati-hati dalam membeli bahan makanan.
\end{abstract}

Kata Kunci: Formalin, Tahu, Spektrofotometri, Fenilhidrazin

\begin{abstract}
The Food and Agriculture Organization (FAO) and the World Health Organization (WHO) state that food additives are ingredients that are added intentionally to food in small amounts to improve color, shape, taste, texture, or as a preservative. According to PerKBPOM No. 2 of 3013 concerning Hazardous Materials that are misused in food, one of which is formalin. This study aims to analyze the content of formalin in tofu which is likely to be circulating in traditional markets in Bulukumba district. The sampling technique used is Total Sampling. The formalin qualitative analysis method was carried out by the phenylhydrazine method and the quantitative analysis by the spectrophotometric method. Tofu samples were taken at the Pasar Subdistrict of Ujung Bulu, Bulukumba Regency. The results showed that from 10 tofu samples purchased from 10 sellers, there were 3 tofu samples containing formaldehyde (30\%). The levels of formalin in the tofu samples at the three sellers were $10 \mathrm{ppm}, 9.8 \mathrm{ppm}$, and $9.5 \mathrm{ppm}$. It is recommended to traders not to use formalin as a food additive and the public to be careful in buying food ingredients.
\end{abstract}

Keywords: Formalin, Tofu, Spectrophotometry, Phenylhydrazine 


\section{PENDAHULUAN}

Menurut undang-undang Nomor 7/1996 tentang pangan, bahwa keamanan pangan adalah kondisi dan upaya untuk mencegah pangan dari kemungkinan cemaran biologis, kimia dan benda lain yang mengganggu, merugikan dan membahayakan kesehatan manusia. Pangan yang tidak aman dapat menyebabkan penyakit yang disebut dengan foodborne disease, yaitu gejala penyakit yang timbul akibat mengomsumsi pangan yang mengandung bahan/senyawa beracun atau organisme patogen (Sucipto, 2015).

Penambahan pengawet pada produk pangan merupakan salah satu upaya untuk mencegah atau mengurangi kerusakan produk pangan. Penggunaan pengawet perlu dipahami baik oleh pihak industri pangan maupun setiap individu yang terkait dengan produksi pangan. Senyawasenyawa yang memiliki fungsi sebagai pengawet, namun dapat memberikan efek negatif terhadap kesehatan, dilarang digunakan sebagai bahan tambahan pangan. Senyawa-senyawa yang dilarang tersebutantara lain: formalin, asam borat, asam salisilat, dietilpirokarbonat, kloramfenikol, dan nitrofurazon (Wijaya dkk, 2012).

Formalin merupakan larutan formaldehid $\quad 35-40 \%$ yang di klasifikasikan sebagai disinfektan kuat.
Walaupun formalin sangat berbahaya jika terhirup, terabsorbsi melalui kulit atau termakan, tetapi formalin sering disalah gunakan sebagai pengawet makanan(Saptarini dkk, 2011)

Formalin bukan pengawet untuk bahan makanan dan produk olahan. Tetapi sampai saat ini, penggunaan formaldehida dalam bahan makanan masih umum. Padahal, pendidikan gizi dan keamanan pangan bagi masyarakat masih kurang (Wikanta, 2010). Ada kemungkinan formaldehid digunakan dalam pengawetan susu, tahu, mie, ikan asin, dan ikan basah (Azmiyawati, 2007).

Formaldehid dapat masuk kedalam tubuh dengan jalan inhalasi uap, kontak langsung dengan larutan yang mengandung formalin ataudengan jalan memakan atau meminum makanan yang mengandung formalin (Sucipto, 2015).

Tahu adalah gumpalan protein kedelai yang diperolah dari penyaringan kedelai yang telah digiling dengan penambahan air. Penggumpalan protein dilakukan dengan cara penambahan garamgaram kalsium, misalnya kalsium sulfat yang dikenal dengan nama batu tahu, batu coko, atau batu sioko(Sarwono dan Saragih, 2004).

Tahu juga dikenal sebagai makanan rakyat karena harganya yang murah, dapat dijangkau oleh masyarakat lapisan bawah sekalipun. Selain harganya yang murah, 
tahu disukai karena dapat diolah menjadi berbagai macam menu dan masakan seperti tahu isi, semur tahu dan lain-lain (Sarwono dan Saragih, 2004).

Tahu sering kali disebut daging tak bertulang karena kandungan gizinya, terutama mutu protein yang setara dengan daging hewan. Bahkan protein tahu lebih tinggi dibandingkan dengan protein kedelai yaitu tahu 0,49 gram sedangkan kedelai 0,39 gram (Sarwono dan Saragih, 2004). Proteinberfungsi untuk pertumbuhan tubuh dan mengganti jaringan yang rusak pada tubuh. Jelas sekali kebutuhan zat protein sudah mutlak dibutuhkan oleh tubuh setiap hari (Restianti, 2009). dilakukan dengan beberapa metode antara lain: Uji Asam Kromatropat, Uji HehnerFulton, uji dengan $\mathrm{FeCl}_{3}$, Uji Fenilhidrazin dan Uji Pereaksi Nash's (Sumantri, 2013). Uji asam kromatopat yaitu pereaksi yang dibuat dengan melarutkan asam 1,8dihidroksinaftalen-3,6-disulfonat dalam $\mathrm{H}_{2} \mathrm{SO}_{4} \quad 72 \% \quad$ (kira-kira) 500mg/100ml (Sumantri, 2013). Uji fenlhidrazin yaitu analisa penetapan adanya aldehid dan keton oleh terbenntuknya fenilhidrazon(Gama, 2014).

Penetapan kadar formalin dapat diketahui dengan menggunakan analisis kauantitatif dengan metode spektrofometri, dalam metode ini menggunakan 2 jenis larutan yaitu asam kromatofat dan larutan
Analisis kualitatif formalin dapat

schiff (Cahyadi, 2008 ). Kadar formalin harus diketahui karena kadar formalin yang tinggi didalam tubuh menyebabkan iritasi lambung, alergi, bersifat karsinogen (menyebabkan kanker), dan bersifat mutagen (menyebabkan perubahan fungsi sel dan jaringan) (Azmiyawati, 2007).

Penelitian ini dianggap penting karena masyarakat menyukai tahu untuk dijadikan sebagai lauk pauk yang hampir dikonsumsi setiap hari, semakin banyak yang membeli tahu maka penjualan tahu juga akan semakin meningkat dan akan mempengaruhi produsen untuk menambahkan formalin dalam tahu agar teksturnya lebih kenyal, keras, tidak berlendir, awet dan tidak mudah hancur, sehingga menarik perhatian kosumen. Tetapi konsumen tidak tahu bahwa adanya formalin dalam tahuakan bersifat toksik bagi manusia.

Hubungan antara tahu dan formalin sangat erat kaitannya kerena formalin sering ditambahkan kedalam pembuatan tahu, karena kurangnya pengetahuan masyarakat tentang penggunaan formalin yang seharusnya tidak digunakan dalam pangan. Berdasarkan penelitian (Sikanna, 2016)terdapat $66,7 \%$ sampel tahu teridentifikasi mengandung formalin di Palu, begitu juga dalam penelitian (Wahyono dkk., 2016) terdapat $71 \%$ sampel tahu putih positif mengandung formalin di Semarang, dan didalam https://doi.org/10.37362/jkph.v6i2.577 
penelitian (Syarfaini dan Rusmin, 2014) presentase sebesar 33,3\% tahu tidak aman dikonsumsi karena positif mengandung formalin di Makassar.

Data pasar Kabupaten Bulukumba sebanyak 42 pasar yang terdiri dari 10 Kecematan. Kec.Ujung Bulu sebanyak 3 pasar, Kec.Gantarang sebanyak 8 pasar, Kec.Kindang sebanyak 4 pasar, Kec.Ujung Loe sebanyak 4 pasar, Kec.Herlang sebanyak 4 pasar, Kec.Kajang sebanyak 3 pasar, Kec.Rilau Ale sebanyak 5 pasar, Kec.Bulukumba sebanyak 3 pasar, Kec.Bontobahari sebanyak 3 pasar, dan Kec.Bonto Tiro sebanyak 5 pasar.

Berdasarkan latar belakang diatas maka peneliti tertarik melakukan penelitian dengan judul analisis kadar formalin pada tahu yang beredar di Pasar Kecamatan Ujung Bulu Kabupaten Bulukumba. Pasar Kecematan Ujung mempunyai 3 pasar yaitu, Pasar Sentral, Pasar Cekkeng, dan Pasar Kasuara dengan total penjual dari ketiga pasar tersebut adalah 10penjual tahu dengan produksi yang berbeda-beda.

\section{METODE}

Desain penelitian yang digunakan pada penelitian ini adalah desian penelitian eksperimen. Metode penelitian eksperimen adalah kegiatan percobaan yang bertujuan untuk mengetahui suatu gejala atau pengaruh yang timbul sebagai akibat adanya perlakuan(Notoatmodjo, 2010).

Dalam penelitian ini dilakukan analisis kualitatif dengan metode fenilhidrazin untuk mengidentifikasi formalin dalam tahu dan analisis kuantitatif dengan metode spektrofotometri menggunakan larutan asam kromatofat untuk mengetahui kadar formalin dalam tahu.

Penelitian ini dilaksanakan pada bulan Mei sampai Juli 2019. Lokasi pengambilan sampel di Pasar Cekkeng Kasuara, Pasar Cekkeng Ela-ela, dan Pasar Sentral Kecematan Ujung Bulu Kabupaten Bulukumba. Pemeriksaan sampel dilakukan di Laboratorium Analis Kesehatan STIKES Panrita Husada Bulukumba.

Populasi dalam penelitian ini adalah tahu dari 10 penjual tahu di Pasar Kecematan Ujung Bulu yang ada di Kabupaten Bulukumba.

Dalam penelitian ini menggunakan metode sampling total sampling, yaitu semua jumlah populasi adalah jumlah sampel. Sampel dari penalitian ini adalah seluruh tahu dari Pasar Kecematan ujung Bulu Kabubaten Bulukumba sebanyak 10 sampel tahu.

\section{Alat}

Adapun alat yang akan digunakan adalah tabung reaksi, batang pengaduk, penangas air, mortal dan pestel, labu ukur, spektrofotometer, alat destilasi dan erlemeyer. 


\section{Bahan}

Adapun bahan yang akan digunakan adalah Larutan uji fenilhidrazin, $\mathrm{HCl}$, Natrium hidroksida, Larutan baku formalin, $\mathrm{H}_{3} \mathrm{PO}_{4}$, Asam kromatofat, Natrium prusid dan Aquades

\section{Prosedur}

a. Prosedur pemeriksaan tahu dengan menggunakan metode fenilhidrazin untuk mengidentifikasi formalin pada tahu.

Larutan uji ditambahakan 10 tetes fenilhidrazin dan HCL 5\%. Setelah itu ditambahkan 2 tetes larutan Natrium prusid $0,5 \%$ tunggu selama 1 menit. Kemudian ditambahakan 10 tetes natrium hidroksida ditunggu selama 1 menit. Timbulnya warna biru yang kemudian berubah menjadi hijau dan akhirnya kuning-maerah menunjukkan adanya formalin.

b. Prosedur pemeriksaan tahu dengan menggunakan metode spektrofometriasam kromatofat.

Dibuat larutan baku induk dari konsentrasi 1000 ppm dari formalin. Setelah itu diencerkan dalam labu 100 $\mathrm{ml}$ dengan aquades sampai tanda batas dan dihomogenkan selama \pm 30 detik. Kemudian larutan tersubut dibuat larutan baku standar. Dimasukkan kedalam tabung reaksi larutan pereksi asam kromatofat sebanyak $5 \mathrm{ml}$. Ditambahkan $1 \mathrm{ml}$ larutan standar formalin sambil diaduk tabung reaksi di tangas selama 15 menit dalam penangas air yang mendidih, angkat dan dinginkan. Dicampurkan 10 gram sampel dengan $50 \mathrm{ml}$ aquades dengan cara menggerusya dengan mortal dan pastel hingga halus. Kemudian didestilat dan diasamkan dengan $\mathrm{H}_{3} \mathrm{PO}_{4}$. Ditampung dengan labu ukur $50 \mathrm{ml}$. Ditambahkan $5 \mathrm{ml}$ asam kromatofat tunggu selama 1 menit. Diukur absorbansi sampel dan standar dengan panjang gelombang $560 \mathrm{~nm}$.

Dihitung kadar formalinnya. Perhitungan kadar formalin dengan pembuatan kurva kalibrasi antara absorbansi dengan konnsentrasi dengan menggunakan persamaan regresi liner.

\section{HASIL}

Berdasarkan Tabel 1 menunjukkan bahwa dari 10 penjual tahu yang berada di Pasar Kecematan Ujung Bulu Kabupaten Bulukumba didapatkan 30\% sampel yang positif mengandung formalin dan $70 \%$ sampel yang negative mengandung formalin.

Persamaan garis yang diperoleh dari Tabel 2 adalah $\mathrm{y}=0,0104 \mathrm{x}-0,0055$ dengan nilai koefesien determinan $\left(\mathrm{R}^{2}\right)=0,8125$ yang menunjukkan korelasi $\mathrm{x}$ dan $\mathrm{y}$ agak kuat kerena mendekati nilai 0,9. Gambar grafik dapat dilihat pada Gambar 1. 
Berdasarkan tabel 3 menunjukkan bahwa dari 3 sampel tahu yang positif didapatkan 1 sampel tahu dengan konsentrasi 10 ppm, 1 sampel tahu dengan konsentrasi 9,8 ppm, 1 sampel tahu dengan konsentrasi 9,5 ppm.

\section{PEMBAHASAN}

Dalam menganalisis kandungan formalin dilakukan beberapa tahap yaitu uji kualitatif dan kuantitatif. Uji kualitatif untuk mengetahui ada atau tidaknya formalin pada tahu menggunakan metode fenilhidrazin. Prinsip metode fenilhidrazin adalah reaksi pembentukan osazon yaitu aldehid atau keton dengan fenilhidrazin dan defenil akan membentuk fenilhidrazon atau osazon.

Uji kuantitatif untuk mengetahui berapa banyak/menganalisis kadarnya formalin dalam tahu menggunakan metode spektrifotometri-asam kromatofatdengan prinsip bila cahaya monokromatik melalui suatu media (larutan), maka sebagian cahaya tesebut diserap, sebagian dipantulkan, dan sebagian lagi dipancarkan.

Identifikasi formalin pada tahu dilakukan dengan cara penambahan fenilhidrazin dengan $\mathrm{HCl}$, lalu di tambahkan Natrium Prusid dan penambahn $\mathrm{NaOH}$. Sampel yang teridentifikasi menggunakan formalin di Pasar Kecematan Ujung Bulu Kabupaten Bulukumba pada uji kualitatif didapakan https://doi.org/10.37362/jkph.v6i2.577
$30 \%$ sampel yang mengandung formalin dan $70 \%$ sampel yang tidak mengandung formalin.

Hasil peneliti lain yang dilakukan oleh Syarfaini dan Rusmin (2014) dalam Al-Sihah: Public Health Science Journal yang berjudul Analisis Kandungan Formalin Pada Tahu di Pasar Tradisional Kota Makassar Tahun 2014 menunjukkan bahwa dari 8 pasar sebagai sampel yaitu terdapat $33,3 \%$ sampel yang tidak aman untuk dikomsumsi karena positif mengandung formalin, dan $66,7 \%$ sampel yang aman untuk dikomsumsi karena negatif mengandung formalin.

Begitupun dengan penelitian Bambang Sri Wahyono dkk (2016) dengan judul Identifikasi Penggunaan Formalin Pada Tahu Putih Di Pasar Kedungmundu dan Randusari Semarang bahwa pasar Kedungmundu menjukkan hasil $71 \%$ (5 dari 7 sampel tahu putih positif mengandung formalin) dan pasar Randusari 67\% (4 dari 6 sampel tahu putih mengandung formalin). Hal ini menunjukkan ada persamaan hasil yang didapatkan dengan peneliti sebelumnya.

Analisis kadar formalin pada tahu dimulai dengan pembuatan kurva kalibrasi. Kurva kalibrasi digunakan untuk menentukan konsentrasi suatu zat dalam sampel yang tidak diketahui dengan membandingkan sampel dengan sampel standard dari konsentrasi yang telah 
diketaui. Pada pengujian kurva kalibrasi konsentrasi yang digunakan adalah 0,5 ppm, 1 ppm, 5 ppm, dan 10 ppm. Kurva kalibrasi larutan standar formlain dengan pereaksi asam kromatofat dengan penambahan asam fosfat dan penambahan asam kromatofat. sampel standar di masukkan kedalam kuvet spektrofotometer dengan panjang gelombang $560 \mathrm{~nm}$. Pembuatan kurva kalibrasi antara konsentasi dan absorbansi sengan mengunakan persamaan linear untuk mengetahui nilai koefesien determinan $\left(\mathrm{R}^{2}\right)$.

Analisis kadar formalin pada tahu yang telah dilakukan dengan asam kromatofat menunjukkan bahwa sampel tahu 01 diberi formalin dengan konsentrasi 10 ppm, sampel 04 diberi formalin 9,8 ppm, dan sampel 09 diberi formalin dengan konsentrasi 9,5 ppm.Formalin tidak diperbolehkan penggunaanya dalam makanan karena dilarang dalam PerKBPOM No. 2 tahun 3013 meskipun kadarnya rendah.

Masalah keamanan pangan seperti tahu perlu menjadi perhatian besar pemerintah dan masyarakat karena dari hasil penelitian menunjukkan bahwa masih adanya pedagang tahu di Kecamatan Ujung Bulu Kabupaten Bulukumba yang menggunakan formalin pada tahu. Makan yang mengandung formalin dengan kadar serendah apapun akan berdampak bahaya pada kesehatan. Formalin yang masuk kedalam tubh secara terus menerus akan mengakitkan penumpukan pada tubuh menyebabkan sakit perut hebat, dan bisa menyebabkan kematian. Munculnya perilaku penambahan formalin pada tahu karena penjual tahu diasumsikan memiliki kecenderungan untuk mengabaikan peraturan-peraturan yang berkaitan dengan pengolahan pangan, temasuk dalam pembuatan tahu. Asumsi tersebut muncul karena adanya target pencapaian keuntungan usaha agar tahu tahan lama atau awet dengan memberikan kepuasan bagi konsumen dengan cara yang tidak dibenarkan.

\section{KESIMPULAN DAN SARAN}

Berdasarkan hasil penelitian, maka dapat disimpulkan bahwa Identifikasi formalin pada tahu yang beredardi Pasar Kecematan Ujung Bulu Kabupaten Bulukumba didapatkan $30 \%$ sampel tahu yang positif menggunakan formalin dan $70 \%$ tidak menggunakan formalin. Kadar formalin pada sampel 01 adalah $10 \mathrm{ppm}$, sampel 04 konsentrasi formalinnya adalah 9,8 ppm dan sampel 09 konsentrasi formalinnya $9,5 \mathrm{ppm}$.

\section{DAFTAR PUSTAKA (REFERENSI)}

AZMIYAWATI, C. 2007. . Zat Kimia Berbahaya Dalam Makanan dan Minuman, Jakarta Selatan, Sunda Kelapa Pustaka.

BPOM \& MENTERI, N. D. 2013. Pengawasan Bahan Berbahaya yang Disalahgunakan dalam Pangan No. 43 Tahun 3013. Jakarta Menteri Dalam Negeri dan BPOM RI. 
CAHYADI, W. 2008 Analisa dan Aspek Kesehatan Bahan Tambahan Pangan Jakarta, Bumi Aksara.

GAMA, T. P. 2014. Kamus Kimia. Kamus Kimia. Pustaka Gama.

RESTIANTI, H. 2009. Pola Makan Dan Keseimbangan Gizi, Bandung, Puri Pustaka.

SAPTARINI, N. M., WARDATI, Y. \& SUPRIATNA, U. 2011. Deteksi Formalin dalam Tahu di Pasar Tradisional Purwakarta.

SARWONO, B. \& SARAGIH, Y. P. 2004. Membuata Neneka Tahu, Jakarta, PT Penebar Swadaya.

SIKANNA, R. 2016. ANALISIS KUALITATIF KANDUNGAN FORMALIN PADA TAHU YANG DIJUAL DIBEBERAPA PASAR DI KOTA PALU. KOVALEN, 2.

SUCIPTO, C. D. 2015. Keamanan Pangan Untuk Kesehatan Manusia, Yogyakarta, Gosyen Publishing.

SUMANTRI, A. R. 2013. Analisis Makanan, Yogyakarta, Gadja Mada University Press.

SYARFAINI, S. \& RUSMIN, M. 2015. Analisis Kandungan Formalin Pada Tahu di Pasar Tradisional Kota Makassar Tahun 2014. Al-Sihah: The Public Health Science Journal, 7.

WAHYONO, B. S., HERSOELISTYORINI, W. \& SUYANTO, A. 2016. IDENTIFIKASI PENGGUNAAN FORMALIN PADA TAHU PUTIH DI PASAR KEDUNGMUNDU DAN RANDUSARI SEMARANG. Jurnal Pangan dan Gizi, 6.

WIJAYA, C. H., MULYONO, N. \& AFANDI, F. A. 2012. Bahan Tambahan Pangan Pengawet, Bogor, IPB Press.

WIKANTA, W. 2010. Persepsi masyarakat tentang penggunaan formalin dalam bahan makanan dan pelaksanaan pendidikan gizi dan keamanan pangan. BIOEDUKASI (Jurnal Pendidikan Biologi), 1. 
Tabel 1. Uji Kualitatif Formalin Pada Sampel Tahu Di Pasar Kecematan Ujung Bulu Kabupaten Bulukumba

\begin{tabular}{ccc}
\hline Pasar & Kode Sampel & Hasil Pemeriksaan \\
\hline Pasar cekkeng kasuara & 01 & Positif \\
Pasar cekkeng kasuara & 02 & Negatif \\
Pasar cekkeng nursery & 03 & Negatif \\
Pasar cekkeng nursery & 04 & Positif \\
Pasar cekkeng nursery & 05 & Negatif \\
Pasar cekkeng nursery & 06 & Negatif \\
Pasar sentral & 07 & Negatif \\
Pasar sentral & 08 & Negatif \\
Pasar sentral & 09 & Positif \\
Pasar sentral & 10 & Negatif \\
\hline
\end{tabular}

Tabel 2. Data Hasil Analisis Standar Formalin dengan Spektrofotometer

\begin{tabular}{cc}
\hline Konsentrasi standar $(\mathbf{p p m})$ & Absorbansi \\
\hline & \\
\hline 0,5 & $-0,004$ \\
\hline 1,0 & 0,025 \\
\hline 5,0 & 0,017 \\
\hline 10,0 & 0,111 \\
\hline
\end{tabular}

Tabel 3. Uji Kuantitatif Formalin Pada Sampel Tahu Di Pasar Kecematan Ujung Bulu Kabupaten Bulukumba

\begin{tabular}{ccc}
\hline Kode sampel & Absorbansi & Konsentrasi (ppm) \\
\hline 01 & 0,096 & 10 \\
04 & 0,093 & 9,8 \\
09 & 0,090 & 9,5 \\
\hline
\end{tabular}

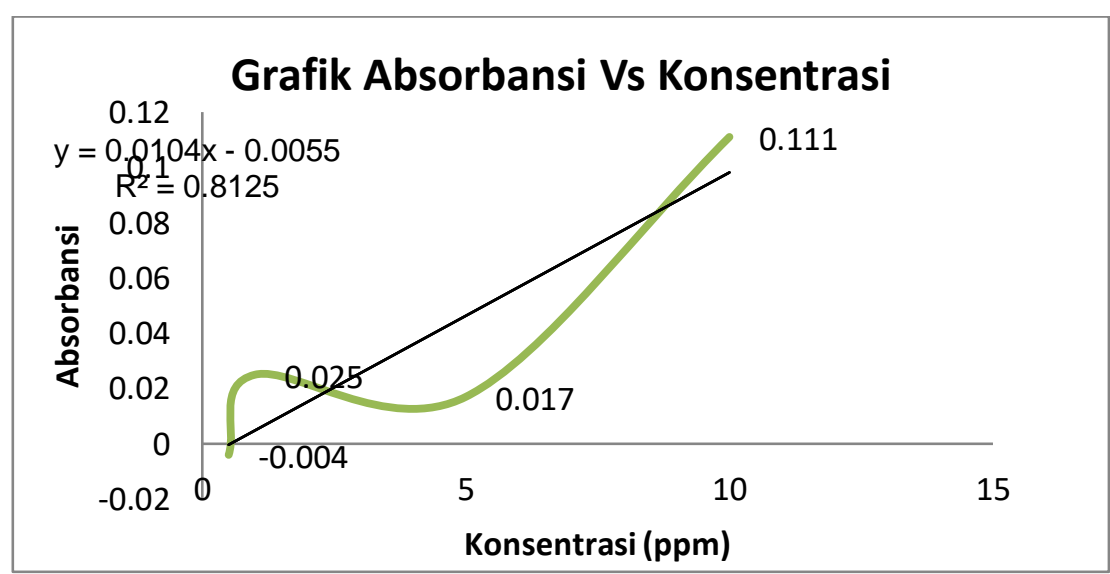

Gambar 1. Grafik Absorbansi vs Konsentrasi 